\title{
実験データにもとづく捨石護岸の被災進行過程のモデル化
}

\section{Modeling of Damage Progression Process for Rubble Mound Seawall Based on Experimental Data}

\author{
太田隆夫 ${ }^{1} \cdot$ 松見吉晴 $^{2} \cdot$ 沜野敦士 $^{3} \cdot$ 佐藤 毅 $^{4}$ \\ Takao OTA, Yoshiharu MATSUMI, Atsushi HATONO and Takashi SATOW
}

\begin{abstract}
Based on the experimental results for profile change of rubble mound seawall, the modeling of damage progression process is discussed in this study. The ranks that indicate the degree of damage for the seawall are determined and the ratio for each rank of damage is obtained from the experimental data. Three models based on the Markov chain model are applied to the transition process of the ratio. The stationary transition probability is obtained for each model and the damage progression is predicted. The model that includes the transition to more than two ranks can predict the transition process of the ratio well.
\end{abstract}

\section{1.はじめに}

社会基盤施設は設計時に設定された性能を供用期間に わたって保持することが求められる. 現在導入が進めら れている性能設計法においても，性能保持に関する検討 が含まれている．しかし，経年変化や外力の作用による 被災 (損傷) で性能の劣化が生じることから，適切な維 持管理を行う必要がある。また，多数の社会基盤施設の 老朽化に対する補修・更新費用の増大が予想されてお り，その観点からも効率的な維持管理が重要となる．社 会基盤施設の適切かつ効率的な維持管理のためには, 施 設の劣化過程を明らかにすることが必要事項の一つであ る。道路舗装や橋梁などについては, 点検・健全度評価 手法や劣化予測手法に関する研究が進められてきた（た とえば，武山ら，1990；保田ら，2004). 海岸保全施設 に対しても，ライフサイクルマネジメントを導入した維 持管理マニュアル（案）（農林水産省・国土交通省, 2008）が作成され, 点検・健全度評価の方法が示されて いる。また，コンクリート構造物を主対象に劣化予測に 関する研究も行われている（小牟禮ら， 2002 ; 横田ら, 2003 ; 辻岡ら, 2004).さらに, 佐藤ら $(2009,2010)$ は 消波ブロック被覆工を対象として予防保全および事後保 全に関する確率モデルを提案し，最適保全方策について 理論的な検討を行っている. しかし，多数の捨石や消波 ブロックで構成される構造物を対象とした劣化過程に関 する検討は未だ数少ないのが現状である。本研究では, 捨石で構成される護岸を対象とした確率的な劣化過程・ 補修モデルの構築を最終的な目的として，まず波の作用 で生じる被災の度合の変化推定を行う。具体的には, 水

\begin{tabular}{|c|c|c|}
\hline 正会員 & 博(工) & 鳥取大学准教授大学院工学研究科 \\
\hline 正会員 & 工博 & $\begin{array}{l}\text { 鳥取大学教授大学院工学研究科 } \\
\text { 鳥取大学大学院工学研究科 }\end{array}$ \\
\hline & 博 (工) & 鳥取大学助教大学院工学研究科 \\
\hline
\end{tabular}

理模型実験で得られた捨石護岸の断面変形のデータにも とづいて被災度の変化 (推移) を求め, その過程に対す るマルコフ連鎖モデルの適用性を検討する.

\section{2. 断面変形計測実験と結果の概要}

本研究で用いる捨石護岸の断面変形デー夕は, 太田ら （2010）の模型実験によるもので，実験とその結果の概 要は以下のようである. 多方向不規則波造波水槽内に, 造波水路（長さ $8.6 \mathrm{~m}$, 幅 $0.6 \mathrm{~m}$, 高さ $0.6 \mathrm{~m}$ ）を 10 基作製 し被覆層とコア部からなる護岸模型を設置した。被覆層 に使用した砕石は密度 $\rho=2.75 \mathrm{~g} / \mathrm{cm}^{3}$, 代表粒径 $D_{n 50}=3.18$ $\mathrm{cm}$ であり，すべての砕石の質量は，70〜 100 gの間にあ る。期待スペクトルにJONSWAPスペクトルを用い，有 義波周期 $T_{1 / 3}=1.2 \mathrm{~s}$ として作成した約 27 分間の一方向不規 則波の信号により造波し，10基の水路で同波形・同位相 の不規則波を護岸模型に作用させた. 1 回の作用波数は 約 1400 波，有義波高 $H_{1 / 3} \cong 11 \mathrm{~cm}$ で，有義波高を用いた安 定数 $N_{S} \cong 2.0$ である. 不規則波を 1 回作用させるごとに, 1 水路あたり 3 測線で護岸の断面形（岸沖方向）をレーザ 一変位センサにより計測し，各測線で初期断面を基準と して断面の変形量を表すパラメータ $S\left(=A_{e} / D_{n 50}^{2}, A_{e}\right.$ : 侵 食面積）を求めた。同じ波を繰り返し作用させて，断面 変形のデータを取得することを 1 回の実験（以下，Test と表記）とし，これを13回行った。Test1のみ波の作用 回数が 6 回であるが, それ以降Test 13 までは繰り返し 7 回 の波を作用させ，合計 2700 個の断面データおよび $S$ の值 を得た。解析の結果として，図-1，2 に示すような波の 作用回数 $N_{r}$ ごとの $S$ の平均值 $S_{m}$ および標準偏差 $\sigma_{S}$ が得ら れ， $N_{r}$ ごとの $S$ の度数分布が $S_{m}$ と $\sigma_{S}$ をもつ正規分布で近 似できることなどがわかった。

また， 1 回の波の作用による被災 (変形) 度の変化特 性に関してつぎのような検討を行った。まず，各測線の 断面データによる $S$ の值を四捨五入して整数值とし, 同 


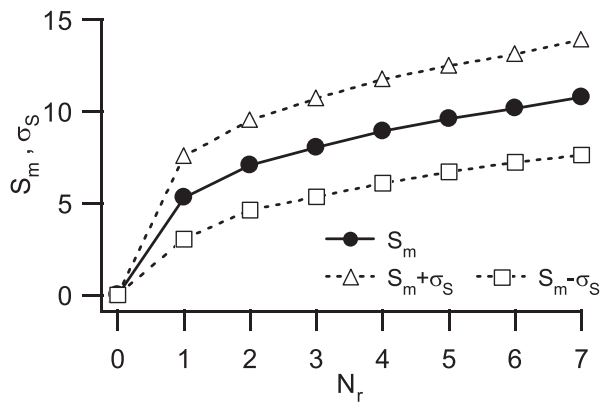

図-1 S の平均值・標準偏差の変化

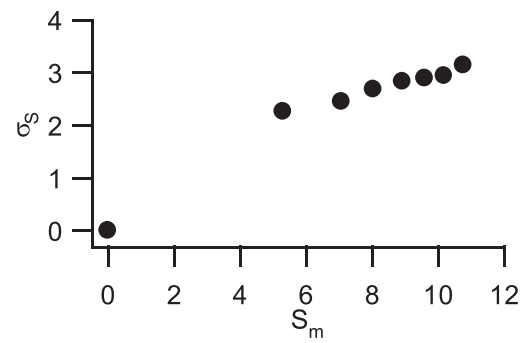

図-2 $\mathrm{S}$ の平均値と標準偏差との関係

一測線で隣り合う作用回数での $S$ の推移に関して $S$ の值 の組み合わせごとに度数を求めた，そのままでは組み合 わせ数が多いことから, 被災度のランク分けを考え, van del Meer（1987）が $S=2$ で初期被災， $S=8$ でコアが露 出するような大きな被災（のり面勾配1:1.5から1:2，2層 被覆の場合）としていることにもとづいて，Sが0から 3 をランク $a, 4$ から 7 をンク $b, 8$ から 11 をンク $c, 12$ 以上をランク $d$ とした. ランクの各組み合わせでの相対 度数を求め, 表-1に示すような結果を得た。

\section{3. マルコフ連鎖モデルの適用性}

表-1の結果は, $N_{r}$ が1から 7の間で被災度の推移をまと めて示したものであるが, $N_{r}$ の各回でランク $a$ から $d$ の 割合（以下，被災度割合と表記）を求めたところ，図-3 に示す被災度割合の推移が得られた。ただし， $N_{r}=0$ は初 期状態で被災度はすべてゼロであることから, ランク $a$ の割合を 1 としている. 図-3から, ランク $a$ の割合は急速 に減少し，逆にランク $d$ の割合は徐々に増加することな どがわかる．本研究では，このような被災進行過程に対 して定常推移確率をもつマルコフ連鎖モデルの適用を検 討した。このモデルは道路舗装, 橋梁や各種コンクリー 卜構造物などの劣化予測モデルとしてもよく用いられて いる（たとえば，前出の武山ら，1990；保田ら，2004； 小牟禮ら，2002；横田ら，2003)。ここでは，モデル 1 ； 被災度は 1 ランクずつ推移しランク間の推移確率はすべ て等しい，モデル 2 ; 被災度は 1 ランクずつ推移し推移
表-1 被災度の変化

\begin{tabular}{|c|c|c|c|c|c|}
\hline & & \multicolumn{4}{|c|}{$N_{r}+1$} \\
\hline & & $a$ & $b$ & $c$ & $d$ \\
\hline \multirow{4}{*}{$N_{r}$} & $a$ & 0.218 & 0.642 & 0.134 & 0.006 \\
\hline & $b$ & & 0.563 & 0.416 & 0.021 \\
\hline & $c$ & & & 0.731 & 0.269 \\
\hline & $d$ & & & & 1 \\
\hline
\end{tabular}

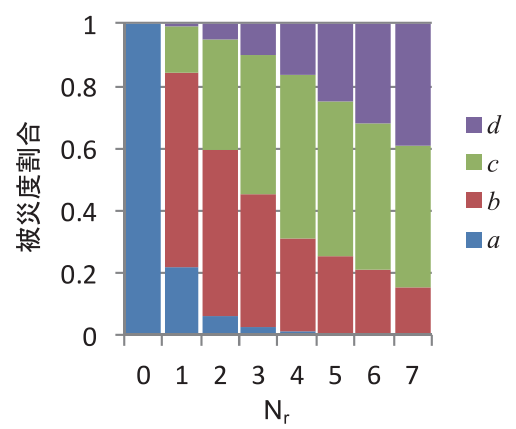

図-3 被災度割合(実験值)

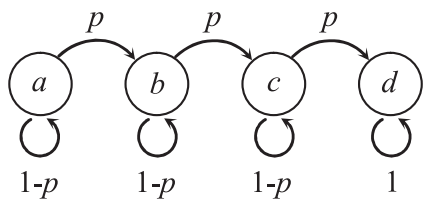

(a) モデル 1

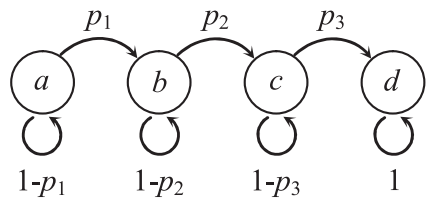

(b) モデル 2

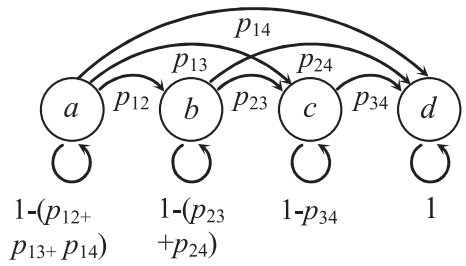

(c) モデル 3

図-4 各モデルの状態推移図

確率はランク間でそれぞれ異なる，モデル $3 ; 2$ ランク 以上の被災度の推移が生じ推移確率はランク間でそれぞ れ異なる，の3 種類のマルコフ連鎖モデルを使用する. 各モデルの状態推移は図-4のように表され, 図中の $p$ は 推移確率である. 本研究では補修を考慮しないため被災 度が大きいランクへの推移のみが生じ, ランク $d$ が最終 
状態であることからdに留まる確率は1である。また， 各モデルにおける波の作用回数 $N_{r}$ での被災度割合は, 式 (1) から（3）で与えられる.

$$
\begin{aligned}
& \left(\begin{array}{l}
a \\
b \\
c \\
d
\end{array}\right)=\left(\begin{array}{cccc}
1-p & 0 & 0 & 0 \\
p & 1-p & 0 & 0 \\
0 & p & 1-p & 0 \\
0 & 0 & p & 1
\end{array}\right)^{N_{r}}\left(\begin{array}{l}
1 \\
0 \\
0 \\
0
\end{array}\right) \\
& \left(\begin{array}{l}
a \\
b \\
c \\
d
\end{array}\right)=\left(\begin{array}{cccc}
1-p_{1} & 0 & 0 & 0 \\
p_{1} & 1-p_{2} & 0 & 0 \\
0 & p_{2} & 1-p_{3} & 0 \\
0 & 0 & p_{3} & 1
\end{array}\right)^{N_{r}}\left(\begin{array}{l}
1 \\
0 \\
0 \\
0
\end{array}\right) \\
& \left(\begin{array}{l}
a \\
b \\
c \\
d
\end{array}\right)= \\
& \left(\begin{array}{cccc}
1-\left(p_{12}+p_{13}+p_{14}\right) & 0 & 0 & 0 \\
p_{12} & 1-\left(p_{23}+p_{24}\right) & 0 & 0 \\
p_{13} & p_{23} & 1-p_{34} & 0 \\
p_{14} & p_{24} & p_{34} & 1
\end{array}\right)^{N_{r}}\left(\begin{array}{l}
1 \\
0 \\
0 \\
0
\end{array}\right) \cdots
\end{aligned}
$$

これらの式における推移確率の推定は, Microsoft Excel 2007 (以下, Excelと表記) を用いてつぎのような 手順（港湾空港技術研究所，2007）で行った。まず，ワ ークシート内に上記のモデル 1 から 3 における推移確率 の初期值として $(0,1)$ の任意の值を与え, 式（1）から （3）で表される被災度割合の推移を $N_{r}=1,2, \cdots, 7$ について 計算する。 $N_{r}=7$ での被災度割合の実験值（図-3参照）と 計算值から誤差の2乗和を求める. Excelのソルバー機能 を用いて誤差の2乗和を最小にする推移確率を算出する. ソルバー機能のパラメータ設定における制約条件および オプション設定の追加事項としては, 推移確率をすべて 1 未満の值とすることと非負数の仮定のみであり，その 他は初期設定のままとした. モデル 1 では推移確率 $p$ の 初期值によらず同じ推定結果が，モデル 2 では $p_{1}$ から $p_{3}$ の初期值をすべて 0.1 とした場合を除いて同じ推定結果 が得られた。モデル 3 では $p_{12}$ から $p_{34}$ の初期值によって推 定結果が異なったため, 初期值の設定と推定結果の両方 に表-1の結果を参照して, 妥当と思われる初期值を決め た. 表-2に各モデルの推移確率の推定值を示す.上述の $N_{r}=7$ における推移確率推定後の誤差の 2 乗和は, モデル 1 で約 0.028 , モデル 2 と 3 では $10^{-14}$ のオーダーであった.

以上の手順で推定した各モデルの推移確率と式（1） から（3）を用いて， $N_{r}=20$ までの被災度割合を求めた。 また，それらの結果を評価するために，実験結果にもと づき以下のようにして $N_{r}=8 \sim 20$ の被災度割合を推定し た。まず， $S_{m}$ と $\sigma_{S}$ の実験值（図-1，2参照）に対して図5,6 の実線で示す近似曲線を当てはめた. それぞれの近 似式は式（4)，（5）のように表される.

$$
\begin{gathered}
S_{m}=5.390 N_{r}^{0.3588} \\
\sigma_{S}=1.038 S_{m}^{0.4553}
\end{gathered}
$$

図-6の点線は，Melbyら（1998）が傾斜堤を対象とした 実験結果から与えたもので，近似式は $\sigma_{S}=0.5 S_{m}^{0.65}$ である が，太田ら（2010）の実験結果ではSのばらつきがより大 きいことがわかる. $N_{r}=8 \sim 20$ の $S_{m}$ と $\sigma_{S}$ を式 (4)，(5）で 与え, $S$ の確率分布がこれらの平均值と標準偏差をもつ正 規分布で表されると仮定すると, $S$ の值がランク $a$ からd のそれぞれに入る確率を求めることができる. 本研究で はシンプソン則を用いた数值積分により正規分布の分布

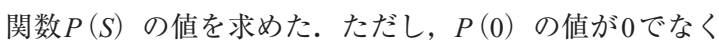
各ランクに入る確率の和が 1 とならないため, $P(0)$ を各 ランクの確率の比にしたがって配分した。図-7に, マル コフ連鎖モデル 1 から 3 と正規分布を用いて計算した $N_{r}=$ 20 までの被災度割合を示す。ただし，（d）の $N_{r} \leq 7$ は図-3

\begin{tabular}{|c|c|c|c|}
\hline モデル 1 & 推定值 & モデル 3 & 推定値 \\
\hline $\mathrm{p}$ & 0.3287 & $\mathrm{p}_{12}$ & 0.4045 \\
\hline モデル2 & & $\mathrm{p}_{13}$ & 0.0843 \\
\hline $\mathrm{p}_{1}$ & 0.4954 & $\mathrm{p}_{14}$ & 0.0065 \\
\hline $\mathrm{p}_{2}$ & 0.3433 & $\mathrm{p}_{23}$ & 0.2729 \\
\hline $\mathrm{p}_{3}$ & 0.2075 & $\mathrm{p}_{24}$ & 0.0370 \\
\hline & & $\mathrm{p}_{34}$ & 0.1508 \\
\hline
\end{tabular}
に示した実験值である.これらの図より，モデル $1,2,3$ の順でランク $a$ の減少が緩やかで $d$ の増加が急であること がわかる．また，図-8はランク別の割合の変化を表した ものである. 以上の結果より，マルコフ連鎖モデルのう

表-2 推移確率の推定值

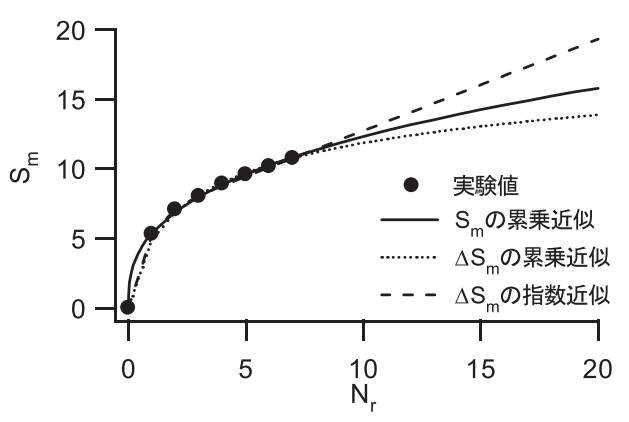

図-5 $S_{m}$ の近似

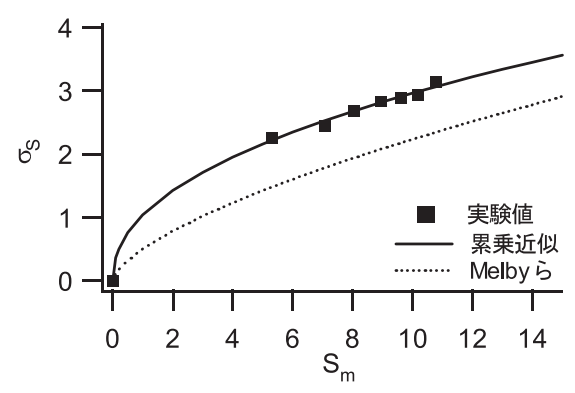

図-6 $\sigma_{S}$ の近似 
ち実験結果にもとづく被災度割合の推移傾向に近いのは モデル 3 であり，2ランク以上の推移を考慮したモデルが 最もよく現象を表していると考えられる.

\section{4. $S$ の変化特性が異なる場合の検討}

3.では図-5の実線で示した $S_{m}$ の変化にもとづいて被災 度割合の推定を行った。ここでは， $S_{m}$ の実験值に関する 近似を変えることによって異なる $S_{m}$ の変化過程を作成 し，これにより被災度割合を求めて，その推移に及ぼす 影響を3.の結果と比較することで検討する。図-9の○は 隣り合う $N_{r}$ での $S_{m}$ の増分 $\Delta S_{m}$ であり, この值に対して累
乗近似と指数近似により図中に示す近似曲線と近似式を 得た。これらの近似式で与えられる $\Delta S_{m}$ より $N_{r}=1 \sim 20$ の $S_{m}$ を求めた。 ただし, 累乗近似による $S_{m}$ は, 実験值に近 くなるように $N_{r}=1$ での值を調整した。図-5に示した点線 が累乗近似, 破線が指数近似によるもので, それぞれの $S_{m}$ に対する $\sigma_{S}$ は式（5）で与えた. 図-5から， $\Delta S_{m}$ の累乗 近似にもとづく $S_{m}$ は $N_{r} \geq 8$ でより緩やかに増加し, 指数 近似によるものは最も勾配が大きく $N_{r} \geq 8$ で直線状に増 加することがわかる. Melbyら（1998）は，Sの平均值が 収束傾向を示さず累積作用波数につれて増加を続けるよ うな実験結果を示していることから， $S_{m}$ が直線的に増加

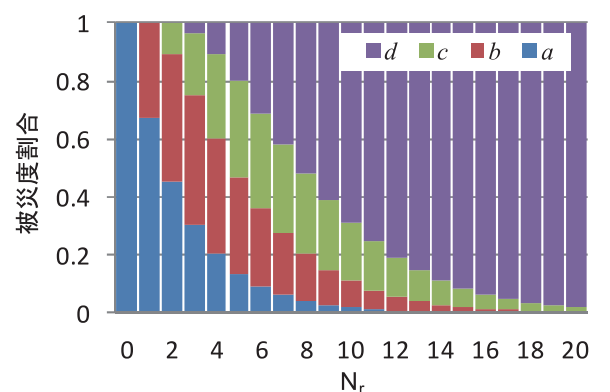

(a) モデル 1

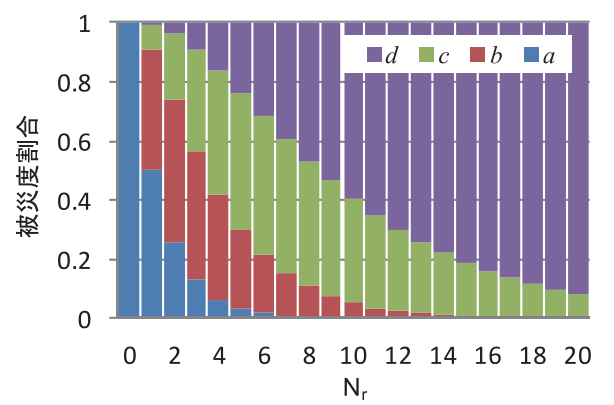

(c) モデル 3

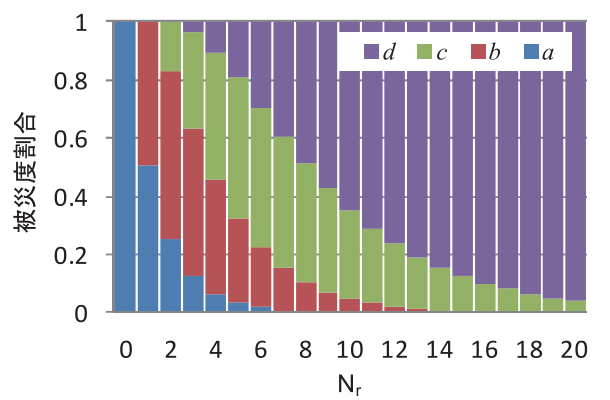

(b) モデル 2

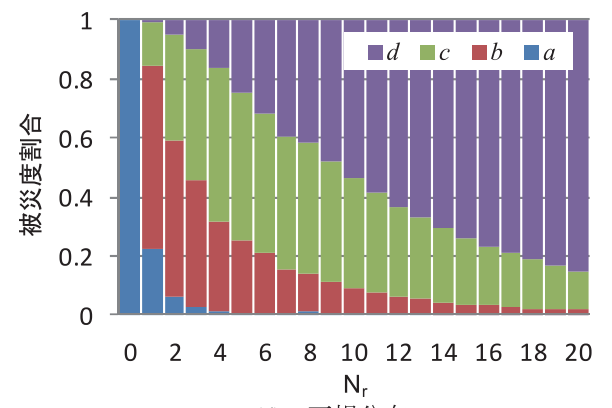

(d) 正規分布

図-7＼cjkstart被災度割合(モデルと正規分布)

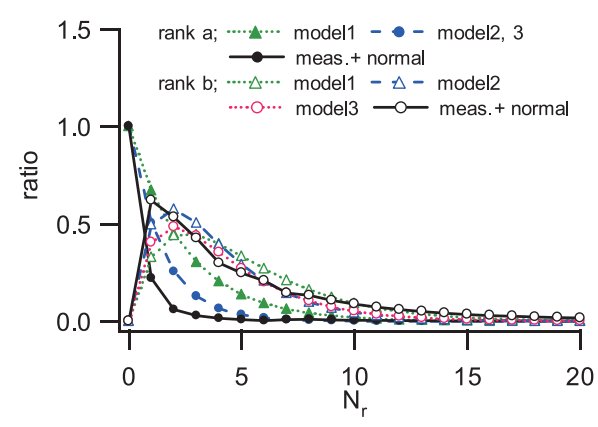

(a) ランク a, b

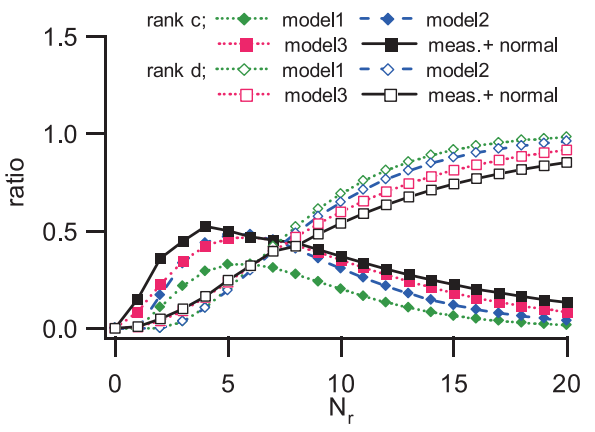

(b) ランク c, d

図-8 ランク別の割合の変化(モデルと正規分布) 


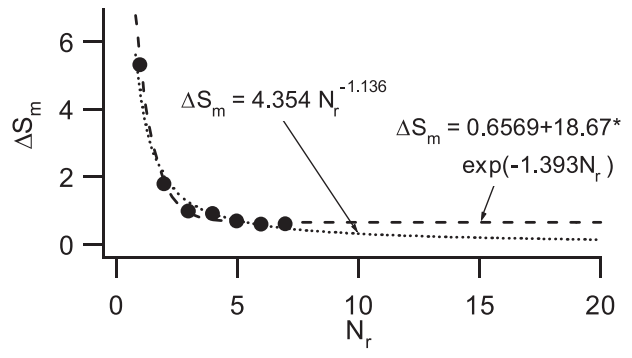

図-9 $S_{m}$ の増分の近似

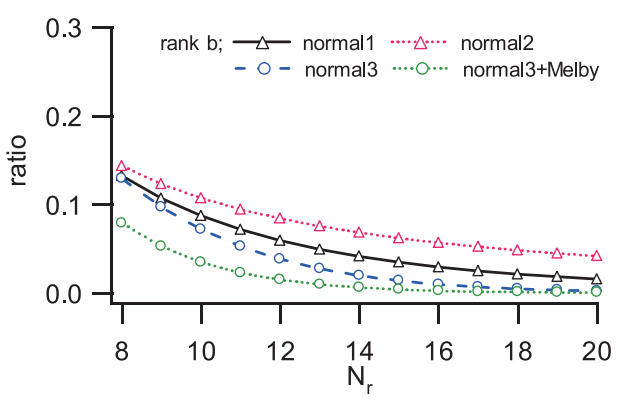

(a) ランク b

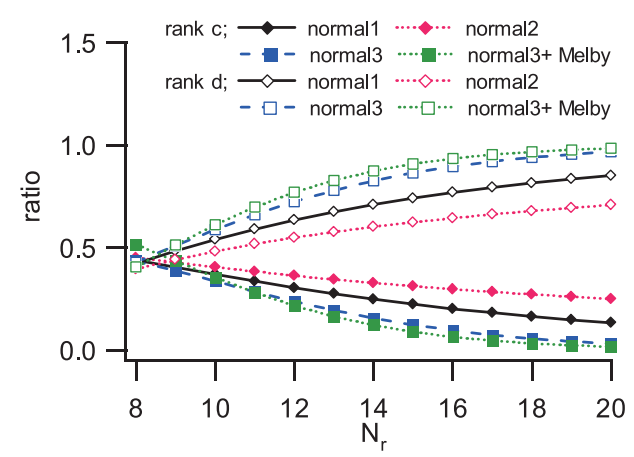

(b) ランク c, d

図-10 ランク別の割合の変化(正規分布)

するような変化過程もあり得ると考えられる。ささらに， $\sigma_{S}$ の差異による影響を検討するために, $\Delta S_{m}$ の指数近似 による $S_{m}$ と Melbyら（1998）が与えた $\sigma_{S}=0.5 S_{m}^{0.65}$ を組み 合わせたケースも設定した。以上の3ケースについて， $S_{m}$ を平均値， $\sigma_{S}$ を標準偏差とする正規分布を用いて， $S$ の值がランク $a$ から $d$ のそれぞれに入る確率を求めた. 図-10は $N_{r} \geq 8$ でのランク $b$ から $d$ の割合を示したもので ある。図中のnormal1 は $S_{m}$ の累乗近似による值で図-8の 実線で示したのと同じもの, normal2 は $\Delta S_{m}$ の累乗近似， normal3 は $\Delta S_{m}$ の指数近似にもとづくもので, normal3+Melby は normal3 と Melbyら（1998）の式による $\sigma_{S}$ を用いたものである. ランク $b, c$ の減少とランク $d$ の 増加の緩急は図-5の $N_{r} \geq 8$ での緩急に対応していること，
$S_{m}$ の変化が同じでも標準偏差の小さいほうがランク $b, c$ の減少と $d$ の増加の早いことが示されている。また，図8 と 10 との比較より, $S_{m}$ が直線的に増加する normal3では, 結果的にランク $c, d$ の割合がマルコフ連鎖モデル 2 によ る值に近くなっていることがわかる.

\section{5.おわりに}

本研究では, 水理模型実験で得られた捨石護岸の断面 変形のデー夕にもとづいて, 変形量パラメータ $S$ の值に よって被災度をランク分けし被災度割合打よびその推移 を求め, 被災進行過程に対して定常推移確率をもつ 3 種 類のマルコフ連鎖モデルの適用性を検討した．各モデル に対して推移確率が得られ，これにより被災度割合を算 出した結果，2ランク以上の推移を考慮したモデルが最 もよく現象を表すことがわかったままた，Sの変化特性 が異なる場合について，被災度割合の推移に及ぼす影響 を検討した，今後は，補修を考慮したより実用的なモデ ルを構築する予定である。

\section{参 考 文 献}

太田隆夫・松見吉晴・山口秀樹 - 木村 晃（2010）：捨石護 岸の断面変形量の統計的特性について, 土木学会論文集 B2 (海岸工学), Vol.B2-66, No.1, pp.871-875.

港湾空港技術研究所編著（2007）：港湾の施設の維持管理技 術マニュアル，沿岸技術研究センター, 229p.

小牟禮建一・濱田秀則・横田 弘・山地 徹 (2002) ：RC栈 橋上部工の塩害による劣化進行モデルの開発，港研報告， 第 41 巻第 4 号, pp.3-37.

佐藤毅 - 松見吉晴 - 角勇人 ·平山隆幸 - 太田隆夫 （2009）：供用期間を考慮した消波ブロックの損傷度に基 づく予防保全問題，土木学会論文集 B2（海岸工学），Vol. B2-65, No.1, pp.951-955.

佐藤 毅 - 松見吉晴 - 平山隆幸 - 角 勇人 - 太田隆夫 （2010）：消波施設耐力と外的負荷を考慮した応急処置を 伴う年齢型予防保全問題, 土木学会論文集B2 (海岸工学), Vol.B2-66, No.1, pp.931-935.

武山 泰・嶋田洋一・福田 正（1990）：マルコフ連鎖モデ ルによるアスファルト舗装の破損評価システム，土木学 会論文集，第420号/V-13，pp.135-141.

辻岡信也・横田 弘・関根好幸・稲田 裕（2004）：劣化・ 変状を含む海岸保全施設の破壞確率算定手法に関する研 究, 海岸工学論文集, 第 51卷, pp.1331-1335.

農林水産省・国土交通省（2008）：ライフサイクルマネジメ ントのための海岸保全施設維持管理マニュアル（案）～ 堤防・護岸・胸壁の点検・診断〜, $105 \mathrm{p}$.

保田敬一・小林潔司（2004）：BMSにおける点検結果と状態 推移確率がLCCに及ほすす影響，建設マネジメント研究論 文集, Vol.11, pp.111-122.

横田 弘・岩波光保・関根好幸（2003）：海岸保全施設の老 朽化実態とその進行モデルの構築，海岸工学論文集，第 50卷, pp.911-915.

Melby, J. A. and N. Kobayashi (1998) : Progression and variability of damage on rubble mound breakwaters, J. Waterw., Port, Coastal, and Ocean Eng., Vol.124, No.6, pp.286-294.

Van der Meer (1987) : Stability of breakwater armour layers design formulae, Coastal Eng., Vol.11, pp.219-239. 